\title{
Teaching Italian Romanticism through Philately and Choral Works
}

Ilona Klein

Brigham Young University, ilona_klein@byu.edu

Follow this and additional works at: https://scholarsarchive.byu.edu/facpub

Part of the Italian Language and Literature Commons

\section{Original Publication Citation}

Klein, Ilona. "Teaching Italian Romanticism through Philately and Choral Works," Essays in Romanticism 28 (2) 2021: 127-143

\section{BYU ScholarsArchive Citation}

Klein, Ilona, "Teaching Italian Romanticism through Philately and Choral Works" (2021). Faculty Publications. 5538.

https://scholarsarchive.byu.edu/facpub/5538 
Klein 1

\title{
Klein, Ilona. "Teaching Italian Romanticism through Philately and Choral Works," Essays in Romanticism 28 (2) 2021: 127-143
}

\author{
$* * * * * * * * * * * * *$ \\ Teaching Italian Romanticism through Philately and Choral Works \\ Ilona Klein \\ Brigham Young University \\ A postage stamp is evidence of a fee paid for postal services and is \\ issued under authority of a government. Usually a small, printed piece \\ of rectangular, adhesive paper attached to an envelope or package, \\ a postage stamp signifies that the sender has fully or partly paid for \\ delivery.
}

[DanteOnStamps.com]

Unlike my own, more seasoned, generation, today's students are decidedly visual and multi-sensory learners ${ }^{1}$ Thus, classroom realia have become ever-more vital tools to be incorporated into discussions and lectures, for by allowing tactile and visual stimuli, the students can in turn create springboards for meaningful peer-group discussions in class, which expand on the scope of the lecture topic at hand. With this observation in mind, over the years I have tried as much as possible to structure my lectures on Italian Romanticism in an interdisciplinary way, so as to bring to my class a breadth of different threads of interest that match the intellectual diversity of undergraduate majors enrolled in the course. My academic training in the Humanities has provided me with an intellectual passion for, and commitment to, the myriad aspects of learning. The Humanities have fostered in me a life-long curiosity about the discipline's multifaceted manifestations: politics, cultures, arts, sciences, geography, spatial explorations, literatures, music, and so much more. The broad horizons of the Humanities allow teachers and students to contemplate bridges and interdisciplinary connections that are almost limitless. They can serve as a network that weaves together many subjects in most creative ways. In my experience, both music - and specifically choral-music works - and philately are truly useful pedagogical tools to fulfill these goals within academic literary courses. Intellectual bridges between disciplines are narrow passageways that must be focused in order to work well. They are useful in class, for they help students refine their thought process and writing skills.

\footnotetext{
1 My gratitude goes to Christopher Kleinhenz (Professor Emeritus of Italian, University of Wisconsin-Madison) and to Madison U. Sowell (Professor Emeritus of Italian and Comparative Literature, Brigham Young University) who have suggested helpful revisions on a draft of this essay. Harold Hendricks (Brigham Young University) has graciously assisted me with the formatting of the images.
} 
Bridges of knowledge between different forms of art are not one-way structures: they can connect sentiments, visuals, facts, intuitions, analyses, theories, poetic structures, texts, and outcomes in many surprising and constructive ways. Bridges are the opposite of walls: they widen our horizons; they enable us to reach out further; they encourage us to embrace new ideas; they are expansive and inclusive. Bridges can assume unusual forms: a rainbow, for example, is a bridge in its own way. ${ }^{2}$ Students are inquisitive and creative, and can build solid bridges between disparate subjects that will surprise and delight teachers. Some of these connections are grounded in artistic relationships, and music holds a privileged position, because sound connects the things we hear but cannot see to those we see, but cannot hear. Given the complexity of teaching the principal characteristics of Italian Romanticism, I use music and postage stamps as added pedagogical artifacts, for they allow for a richer canvas on which to build and analyze the topics treated during the semester. By having stamps play a historical narrative part in class, I give students a tangible opportunity to detect through them the political, artistic, and literary mood of the period. ${ }^{3}$ Moreover, Italian Romantic literature and choral music have a direct intersection through the close link of Alessandro Manzoni and Giuseppe Verdi who are inextricably connected, and by more than just Verdi's Messa da Requiem, first performed on 22 May 1874 in the church of San Marco in Milan, on the one-year anniversary of Manzoni's death. The two men deeply admired each other, were interested in portraying the intricacies of life's vicissitudes and emotions, and were both modest human beings who disliked ceremonial recognitions. Verdi was younger than Manzoni by almost three decades, and their social and economic backgrounds were quite different. Manzoni was squarely integrated in the noble Milanese intelligentsia, his mother Giulia was the daughter of Cesare Beccaria (1738-94), the famous proponent of criminal justice reform and author of Dei delitti e delle pene (On Crimes and Punishments). Manzoni's father, Giovanni Verri, was the brother of Pietro Verri, the great Milanese philosopher and economist of the eighteenth century. ${ }^{4}$ Verdi was born near Milan, the son of an innkeeper, and, as a youth, had read Manzoni's I promessi sposi (The Betrothed), and longed to meet its author, who by now was internationally recognized as the Italian writer second only to Dante. ${ }^{5}$ In my Italian Romanticism course, postage stamps and choral music help highlight these connections.

2 For more on the symbolism of bridges, see Thomas Harrison, Of Bridges: A Poetic and Philosophical Account (Chicago: University of Chicago Press, 2021).

3 Besides teaching Italian Romanticism with philatelic prompts in class, I also taught Dante's Divine Comedy every other year at Brigham Young University from 1994 to 2019, with the aid of Dante and Divine Comedy postage stamps issued worldwide. For those who might be interested, danteonstamps.com is an excellent source of information. The curator of this website, Christopher D. Cook, has published two books: The 1965 United States Dante Stamp (Columbus, OH: Silver Anchor Press, 2017), and Dante on Stamps. A Septicentennial Catalog (Berrien Springs, MI: Silver Anchor Press, 2021).

4 See Barbara Reynolds, "Verdi and Manzoni: An Attempted Explanation," Music \& Letters 29 (1948): 31-43.

5 See Albert Maecklenburg, "Verdi and Manzoni," The Musical Quarterly 17 (1931): 209-18. 
Nestled in the beautiful Wasatch Front of the Utah Rocky Mountains in Provo (Utah), Brigham Young University is a large research institution with over thirty-two thousand students who hail from all fifty states and scores of foreign countries. Founded in 1875, Brigham Young University offers close to one hundred majors, and it is known for the richness and variety of its foreign-language offerings. The courses in Italian that I teach are linguistically advanced, because almost all of the enrolled students at the 300- and 400-level (most of them Italian language majors and minors) have already engaged in eighteen to twenty-four months of volunteer service in the country of their target language. While conversationally fluent in their foreign language, these students usually return from their residency abroad without the critical skills necessary to analyze the cultural significance of what they have experienced. Most are enthusiastic about the language, and many can read challenging literary texts; however, they often do not have the ability to interpret them within any sort of sophisticated theoretical framework. It is incumbent on theinstructor, therefore, to help them acquire the intellectual tools necessary to read texts critically and learn to use actively in speaking and in writing recognized theoretical vocabulary. Brigham Young University's College of Humanities strongly encourages all enrolled undergraduates to pursue interdisciplinary interests, therefore it is not surprising to find them pursuing a variety of extracurricular and civic activities. In addition, most students at Brigham Young University affiliate with the Latter-day Saint religious tradition that fosters from their youth learning a musical instrument and singing in choirs. In fact, music is an integral part of the faith: the most prominent example is the world-renowned Tabernacle Choir at Temple Square. Pedagogically, in my lectures and class assignments, I enjoy focusing on the diversity of my students' backgrounds, interests, innate abilities, and the variety of majors (or double majors) in which they are enrolled, to create teaching modules as interdisciplinary as possible. I encourage them to frame and write their term papers and the class discussions by emphasizing their own multi-disciplinary interests. Doing so allows for richer and deeper intellectual cross-pollination in student-group assignments. I am now a retired faculty member of the Department of French and Italian at Brigham Young University, where I taught the 3-credit, upper-level undergraduate Italian Romanticism course from 1996 to 2019. The twice weekly, seminar-style, 75- minutes course is taught in Italian, as are the texts used. The syllabus includes some of the major writings of Ugo Foscolo, Giacomo Leopardi, and Alessandro Manzoni, while weaving in information about coeval history, politics, music, geography, and language.

Most students enrolled in my classes are part of a generation that is, overall, somewhat unfamiliar with postage stamps. ${ }^{6}$

\footnotetext{
6 As a nine-year old, I caught the stamp-collecting bug from my Italian uncle, Furio Mileti (1930-2017) who lived in Rome, and to whom I dedicate this essay. His father, a philatelist, encouraged Furio to collect stamps during the years of the Fascist regime, and afterwards, when Italy was declared a republic. Philately runs in that side of my family. I have been collecting postage stampssince I was a kid. Initially, I pestered relatives, nagging them to set aside for me all the envelopes with stamps when they received mail. Eventually, I also began to ring at neighbors' doorbells, begging for their discarded envelopes. As a teen, my babysitting jobs financed this passion, and, once out of graduate school, when my job in academe allowed for some discretionary spending, I was able to dedicate more time and attention to philately. The shelf space allotted to my personal postage-stamp albums kept growing. Eventually, when my uncle Furio died, I was honored to receive his personal collection which I added to mine. I wrote this essay during the COVID-19 lockdown. Staying isolated at home provided me with the opportunity to go through my philatelic collection, dedicating a few hours a day, over many months to systematize my holdings. This is probably the only one thing that happened during the pandemic for which I am thankful.
} 
They have, of course, seen stamps, and some may have actually attached stamps to envelopes (wedding invitations, for instance). However, I teach a generation who is fully used to paying bills online, and many have actually never written a check. I need to be aware of the technology with which my students grew up, because that frames their world and defines their comfort zone, and this also separates me from them.

Stamps are stimulating teaching tools, Joseph Kirman and Chris Jackson argue ${ }^{7}$ Frank Nuessel and Caterina Cicogna vouch for the "instructional value" of postage stamps, correctly identifying them as "semiotic artifacts" (210) requiring the collectionist (or the student) to decode their inherent messages. ${ }^{8}$ Thomas Di Napoli helpfully suggests that "students' lack of awareness of those persons, places, and events, which have shaped the country's history as well as their lack of insight into socio-political customs or national policies alien to their own heritage" (193) can be well mitigated by thoughtful classroom discussions, based on what postage stamps depict, and the message they want to convey. ${ }^{9}$ Pauliina Raento and Stanley Brunn marvel at the intrinsic symbolism contained in postage stamps, small pieces of colored printed paper whose images range from monuments, to death masks and to gravestones, to visual political propaganda, to health, tourism, sports, arts, atoms, etc. ${ }^{10}$ Kamil Štěpánek recognizes the importance of the "pictorial source" (98) of postage stamps, which can trigger a continuing interest in students - and all is readily available today on the internet with a quick engine search of key words. ${ }^{11}$

Images of coats-of-arms can lead to understanding general facts about European

7 See Joseph M. Kirman and Chris Jackson, “The Use of Postage Stamps To Teach Social Studies Topics,” The Social Studies 91, no. 4 (2000): 187-90.

8 See Frank Nuessel and Caterina Cicogna, "Postage Stamps as Pedagogical Instruments in the Italian Curriculum," Italica 69, no. 2 (1992): 210-27.

9 See Thomas Di Napoli, "Postage Stamps and the Teaching of GDR Culture and Civilization," Die Unterrichtspraxis / Teaching German 13, no. 2 (1980): 193-205.

10 See Pauliina Raento and Stanley D. Brunn, "Visualizing Finland: Postage Stamps as Political Messengers," Geografiska Annaler. Series B, Human Geography 87, no. 2 (2005): 145-63. See also Richard E. Wood, "Teaching Francophonie with Postage Stamps," Canadian Modern Language Review 36, no. 1 (1979): 105-24.

11 See Kamil Štěpánek, "The State and the Church: Historical Educational Themes on Czechoslovak and Polish Postage Stamps and Their Didactic Potential," Czech-Polish Historical and Pedagogical Journal 10, no. 1 (2018): 98-108. For more on the political value of teaching with postage stamps, see also by the same author, "A Century of Occupations, Political Experiments and Renewed Statehood in Central Europe as Reflected in Postage Stamps (and History Teaching)," Czech-Polish Historical and Pedagogical Journal 11, no. 2 (2009): 57-68. 
monarchies, for instance, and in turn frame a discussion about historical alliances and national wars. Štépánek writes that decoding the information contained on a postage stamp can lead to creative and stimulating conversations among students. Udo Jung, correctly, points out that "the postage stamp [...] represents the way a nation would like to be seen by others" (247). ${ }^{12}$ In other words, postage stamps have represented and still represent the image a nation wants to present to the rest of the world. ${ }^{13}$ The power of nationalistic imagery is even more obvious in stamps issued during periods of dictatorships.

The postage stamp, as we recognize it today, was first conceptualized in England by Sir Rowland Hill (1795-1897), an educator and postal-system reformer.

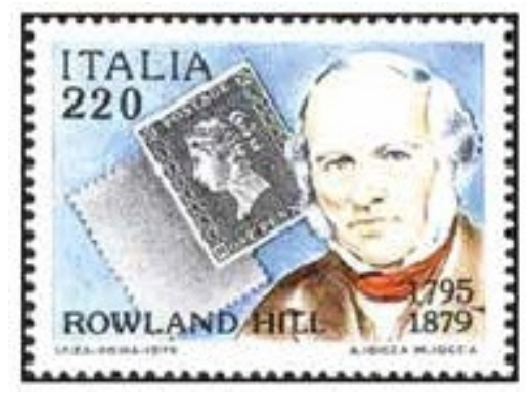

figure 1: Italy, Scott 1386 (1979). Hill.

The first adhesive postage stamp, famously known as the Penny Black, was issued on 1 May 1840, and was valid from 6 May. For several years prior to this invention, Hill had concerned himself with how to create a more efficient way to move letters from one side of the country to another. The centuries-old system was no longer working: the sender of a letter, note, or packet used to rely on a courier to transport and hand deliver the document or object to an addressee, who, upon receipt, was expected to pay what was due for transportation. Increasingly more often, however, the addressee's party refused payment, or was not to be found at the indicated address, or, sometimes, had died. The traditional delivery system was thus becoming less reliable, and the postal system was losing money. Hill proposed a pre-payment method, and from that point on, the sender was responsible for the shipment fee, and the postal service would do its best to deliver to the addressee. If not found, the object would be returned to the sender, without reimbursement. Hill's idea proved winning: he created affordable mailing rates, based on weight rather than on distance, and soon not only aristocrats were making use of the postal system. Jung defines stamps as the "receipt for money collected by the postal service from

12 See Udo O. H. Jung, "Germany through Stamps," Die Unterrichtspraxis / Teaching German 14, no. 2 (1981): 246-59.

13 Francesco Giuliani, La parola pesante . Lingua e letteratura nei francobolli italiani (Foggia: Edizioni del Rosone, 2018) and Federico Zeri, I francobolli italiani. Grafica e ideologia dalle origini al 1948 (Genova: Il Melangolo, 1993). 
the sender" (246). There is great pedagogical value in postage stamps. And there are plenty of affordable and historical stamps circulating. Indeed, some are still attached to their original envelopes ("covers," using philatelic nomenclature). With just a few exceptions, each postage stamp bears the name of the nation issuing it, the value it carries ("denomination"), a highly symbolic and meaningful image, and an edge which is usually "perforated" on older, historic stamps in order to separate them from one another. Much like the value of gold or silver which historically fluctuates, so does the collector's trade value of postage stamps. Over the decades, the rare and most desirable stamps have acquired great value, while stamps that were produced in the hundreds of thousands, or even millions, during the nineteenth century may be worth only a few cents to a collector today. The best way to ascertain the commercial value of any historical postage stamp is to consult the professional philatelic catalog Scott, printed in the United States, currently in six volumes, and updated yearly. All world-wide stamps are cataloged therein. Most public libraries have copies of Scott in their collection. Concerning specifically Italian postage stamps, besides Scott, the website www.ibolli.it is at everyone's fingertips, and every Italian stamp issued is described and valued there.

There are as many different ways to collect stamps as there are stamp collectors. There are also wide variations in how to plan and manage one's postage stamp albums. One may purchase ready-made albums, or simply design and print out stamp collecting pages (an easy DIY way). One may collect "topical" stamps (focusing on one subject, for instance butterflies, or famous singers, or explorers, or authors [e.g., Dante], or planets, or historical leaders, etc.) or one may collect national stamps (for instance, any and all stamps issued in the USA, or in Thailand, or in Turkey, etc.). Some collectors are amateurs, some are professionals. Albert Kunze remarks that stamp collecting can be as expensive or as inexpensive as one wants to make it. ${ }^{14}$

One may buy stamps, or — in today's virtual world — one may simply download images within the public domain, readily available online, and create virtual collections with no expense at all. However one decides to create a philatelic sphere of knowledge, postage stamps offer an easy and natural learning opportunity. One word of caution about purchasing stamps online, rather than from a brick-and-mortar philately store: forgeries and falsifications exist aplenty, especially for the most rare and expensive stamps. While a stamp store is staffed by professionals who can usually spot these, an internet purchase always assumes some risk. One should make sure that returns are accepted in case of dissatisfaction with the item purchased.

When introducing historical postage stamps to my students, I begin by explaining some philatelic basics, so that we can all communicate and understand each other, by using common nomenclature. I explain, for instance, that stamps are classified as "mint" (those that have never been used, and still have the original gum on the back side) or "canceled/postmarked" (the terms may be used interchangeably) indicating stamps that have been used as postage at one time.

14 Albert F. Kunze, "Latin American Postage Stamps and the Teaching of Spanish and Portuguese," Hispania 26, no. 1 (1943): 68-72. 


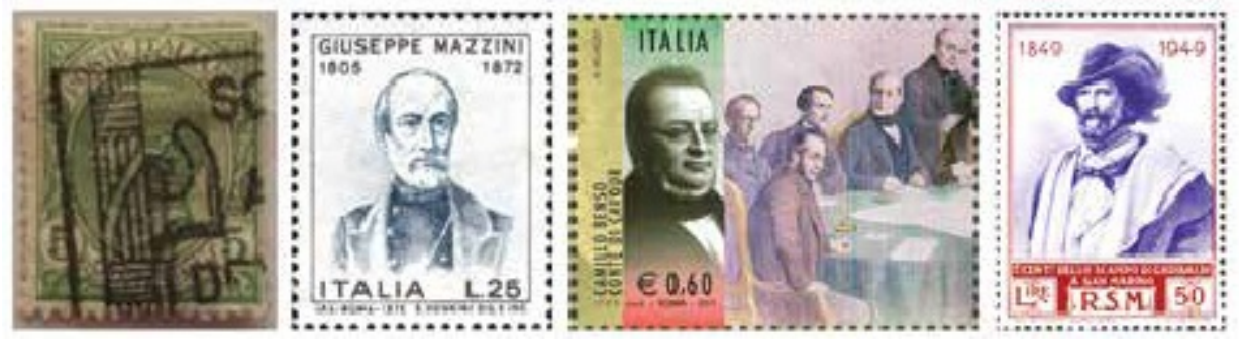

figure 2: Italy, Scott 94, fasces cancellation [author's collection]; Italy, Scott 1059 (1972), Mazzini; Italy, Scott 3062 (2011), Cavour; Italy, Scott 303 (1949), Garibaldi.

The cancellations on a stamp may trigger specific interest, as they may show locations, and/or dates of cancellations, or even a particular image (e.g., the Italian fascist postage cancellation, see FIGURE 2). Stamps (whether mint or used) may have been hinged on the back side if they were once attached to a collector's sheet, likely part of a page album, or there may be only the remnant of a hinge remaining on the back. Stamps may also be collected in albums using philatelic mounts, which do not affect the physical integrity of items. Nations print "regular" issues, as well as "commemorative," or special-occasion issues. Other characteristics that might need explanations to familiarize students with stamps are "perforations" (the rows of small sequential holes that aid in detaching one stamp from the one printed next to it), "watermarks" which are often embedded in the paper used for printing the issues (a way to make counterfeiting more difficult), and printing techniques (the most common methods are lithography, engraving, photogravure, typographic, and embossed). Kunze argues that careful examination of postage stamps leads to the desire of researching the design, the history, people, and animals portrayed, colors used, and other specifics that jump to the eye.

Often, owners of stamp collections arrange items in chronological order, according to the date in which they were issued by each nation. In the classroom, though, my experience has taught me that what best meets students' needs is to order the stamps in chronological order, according to the events celebrated by the images depicted on the stamps. Moreover, when treating Italian Romanticism, the stamps I bring to class are not coeval. The first Italian Kingdom stamp was issued in 1862 (Italy became a nation in 1861). The stamps I use as teaching aid represent postage issued in later years to celebrate moments of past history.

Much like Germany, for centuries Italy was divided, fragmented into many territories and states which slowly were being annexed to the Kingdom of Sardinia, starting around 1848 during the Risorgimento (the movement that led to the unification of the country) through 1860. It was not until the Papal States capitulated, and Rome was conquered in 1870, that the Italian state was finally unified under King Victor Emmanuel II. There are too many protagonists to be counted among the early political strategists who worked to unify Italy. Among those whose role we discuss in class are the better known, i.e., Giuseppe Mazzini, Camillo Benso Count of Cavour, and Giuseppe Garibaldi [FIGURE 2]. 
Within the anti-Enlightenment polemics of the first years of the nineteenth century, two different and apparently opposite political tendencies emerged in Italy: a liberal and a moderate line. Hence, it is difficult to define clearly for my students the Romantic manifestations in Italy, as they encompass many different shades of expression. While Germany had already experienced its first literary Romantic spark with the Sturm und Drang movement in the 1770s and 1780 s, Italian literature - probably weighted down by centuries of canonical Classicism - only began to discuss the merits of a new literary movement in 1816, following the publication in the journal Biblioteca italiana of Mme de Stael's article "Sulla maniera e la utilita delle traduzioni." 15 Certain writers and patriots used the 1816-18 literary polemics in Biblioteca italiana to fight against the Austrian conservative and repressive regime, while at the same time both seeking to retain traditional Italian cultural values and casting the basis for future national revolutions. The Romantic trend in northern Italy was considered politically dangerous by the Austrian regime, and often resulted in censorship.

Between Goethe's publication of Die Leiden des jungen Werthers (The Sorrows of Young Werther 1774$)$ and the birth of Italian Romanticism with its three main authors, Ugo Foscolo (1778-1827), Giacomo Leopardi (1798-1837), and Alessandro Manzoni (1785-1873), there is a hiatus of at least a couple of literary generations. With the provocative title to her book, $I l$ romanticismo italiano non esiste (Italian Romanticism Does Not Exist, 1908), Gina Martegiani claimed that Italy represented but a faint echo within the European debate over Classicism $v$. Romanticism. ${ }^{16}$ Truthfully, the Italian Romantic movement is so fluid in its parameters that students need to be very flexible in their perceptions, rather than trying to compartmentalize Foscolo, Leopardi, and Manzoni. Leopardi, for instance, saw himself as a Classicist, especially in the meter and rhyme schemes of his poetry, which reflect his profound knowledge of Greek and Latin. It is quite ironic that Italy considers him, still today, one of the three main authors of Italian Romanticism. Did Italian Romanticism actually exist? Can it be defended as a legitimate literary movement against the way it was conceived in the other European nations, in their own Romantic expressions? In 1908, Martegiani paradoxically concluded that Italian writings of the time could not be considered "Romantic" because they lacked those essential "Romantic" characteristics common to the other European literatures. Romanticism developed in Italy almost four decades after its neighboring countries. Italian literary traits included authors' interests in political and economic events. Italy, Martegiani observed, was reacting (as Mme De Stael had exhorted) against a long and pedantic stagnation caused by the Classical tradition.

15 See Anne Louise Germaine De Stael, "Sulla maniera e la utilita delle traduzioni," Biblioteca italiana, 1 (1816): 9-18. 
In northern Europe, the Romantic movement encouraged individual heroism, but in Italy political writings were more focused on national ideals of country and unification, implying a sense of collective triumph. Even though some Italian Romantic works mirrored the passion, torment, and personal desperation and drama of the German works of the time, by and large it was national pride (overt or carefully disguised) that permeated mid-nineteenth century Italian literature (Martegiani 77).

When the proto- and pre-Romantic movements in Italy displayed some characteristics parallel to those of other European nations, they were overall mostly theoretical, with a nationalist orientation. Italian verisimilitude was criticized, as it seemed to contrast, two generations later, against the earlier spontaneity and creativity of first-generation English Romantics, such as Samuel Taylor Coleridge, or against Gottfried August Burger's works. As Manzoni perfected in Italy the romanzo storico (historical novel), the Italian movement moved further apart from the rest of Europe, which celebrated instead creative literary spontaneity. There are no easy definitions and answers for this literary movement, and most undergraduate students tend to want some clear guidelines and definitions in their courses. I start the first day by letting them know that we will probably end the semester with more questions than answers, but that the literature they will study is fascinating, stimulating, creative, and thought provoking. I usually am able to put them at ease by allowing them to be confused by the murky Italian Romantic parameters that are inevitably embedded in every class segment.

As I introduce Italian Romanticism in the course, I divide the movement into three main branches. The first is represented by Ugo Foscolo, who writes about the passions and nationalistic aspirations of a proto-Romantic ideal, while still heavily employing a strong Classical rhetorical style. In class, we compare his sonnets to his epistolary novel Ultime lettere di Jacopo Ortis (The Last Letters of Jacopo Ortis). The second branch is represented by Giacomo Leopardi, whom I teach as a realist thinker and philosopher with a strong background education in the Classics, and not - as he is usually known — as a chronic pessimist. His poetic themes are honest and introspective, realistic, Romantic, and sensitive to the existential suffering of human beings. The third branch belongs to the religious, Christian motives of Italian Romanticism, represented by Alessandro Manzoni whose works in poetry and prose present the author as a patriot and a fervent Catholic who forcefully vouched for brotherhood rights to human dignity, and compassion for all. Manzoni inherited Cesare Beccaria's principles of the Italian Enlightenment, creating a foundation for a modern and contemporary understanding of social justice.

The admittedly gray area of the Classic $v$. Romantic dichotomy in Italy presents real challenges for the students enrolled in my class, because until the beginning of the nineteenth century, Italian literature was imbued with the centuries-long tradition of Classicism, but now the two movements intertwined in surprising, constructive ways until Naturalism (defined as verismo in Italian literature) took hold in the late 1870s and early 1880s, mostly with Giovanni Verga. In 1932, the Italian post office issued a set of twelve beautiful stamps, portraying famous Italian authors: Dante, Petrarca ,Boccaccio, Ariosto, Machiavelli, Tasso, Sarpi, Botta, Alfieri, Foscolo, Leopardi, and Carducci (Scott 268-79). 
Klein 10

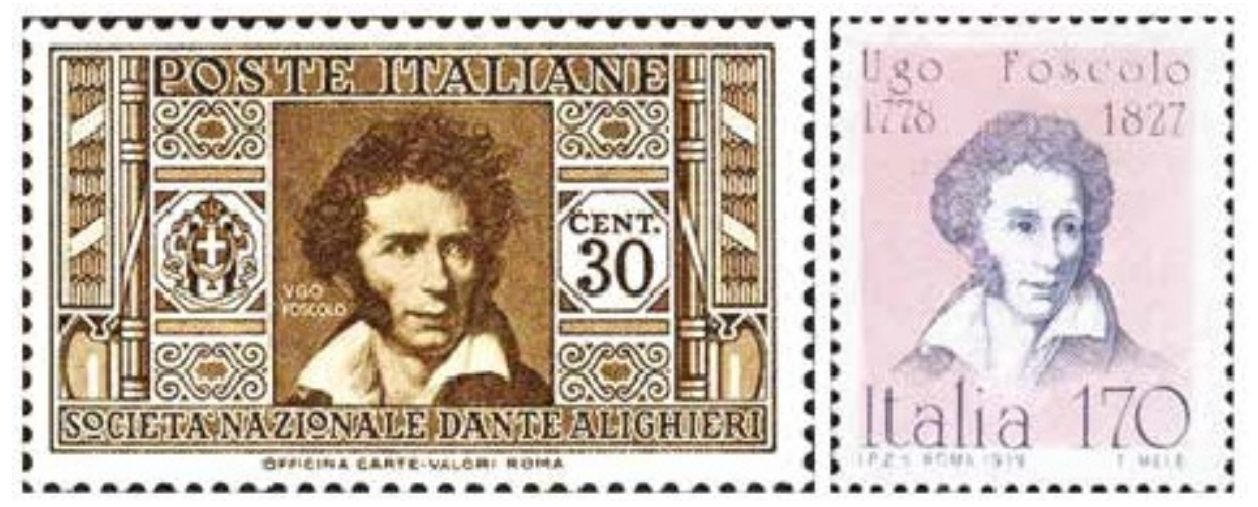

figure 3: Italy, Scott 272 (1932), Foscolo; Italy, Scott 1363 (1979), Foscolo.

When looking carefully at Foscolo's stamp, one sees the two vertical ornaments at the sides clearly boasting the fasces, iconographic symbols of Mussolini's dictatorship, and the coat of arms of the Savoy House [FIGURE 3].

This set of twelve represented a very successful public-relations attempt on the part of the Fascist regime to solidify its myth of a cohesive string of uninterrupted Italian patriots who, over the centuries from the time of Dante, fought for the unification of the nation. As a comparison, another Italian stamp from the late 1970s is much gentler artistically in its portraiture (even though the source image for the two stamps is actually the same) and belongs to a series of five stamps, "uomini illustri" (Famous Italians), celebrating, besides Foscolo, Carlo Maderno, Lazzaro Spallanzani, Massimo Bontempelli, and Francesco Severi (Scott 1361-5). As we analyze and compare both stamps in class, the main question we focus on is why dictatorships display and emphasize in their postage stamps nationalistic symbols, appropriating power and traditions, while other nations under a democratic political system do not? I find students' responses to be thoughtful and well argued.

I introduce Giacomo Leopardi via the letters written by his sister Paolina Leopardi to her own friends, associates, and eventually to Giacomo himself, after he left their hometown of Recanati, in East-Central Italy. Reading Paolina's letters allows a familial female voice to describe life in Recanati. In class, we discuss gender privilege in Italy during the early nineteenth century, and the relationship between these two siblings. Typically, some students are Gender Studies majors or minors, and they bring academic rigor and historical awareness to the conversation. On the large class tech screen, and with the aid of Google Maps, I show where the town's location is, and the home of the Leopardis, so students can orient themselves not only historically, but geographically. I hope that by giving space to the narrative voice of Paolina Leopardi, to her words describing the rigors and strict discipline reigning in the austere home of their father, Count Monaldo Leopardi, my students will not judge the poems and prose of her brother Giacomo Leopardi simply as the work of a pessimist and self-absorbed writer, but 
Klein 11
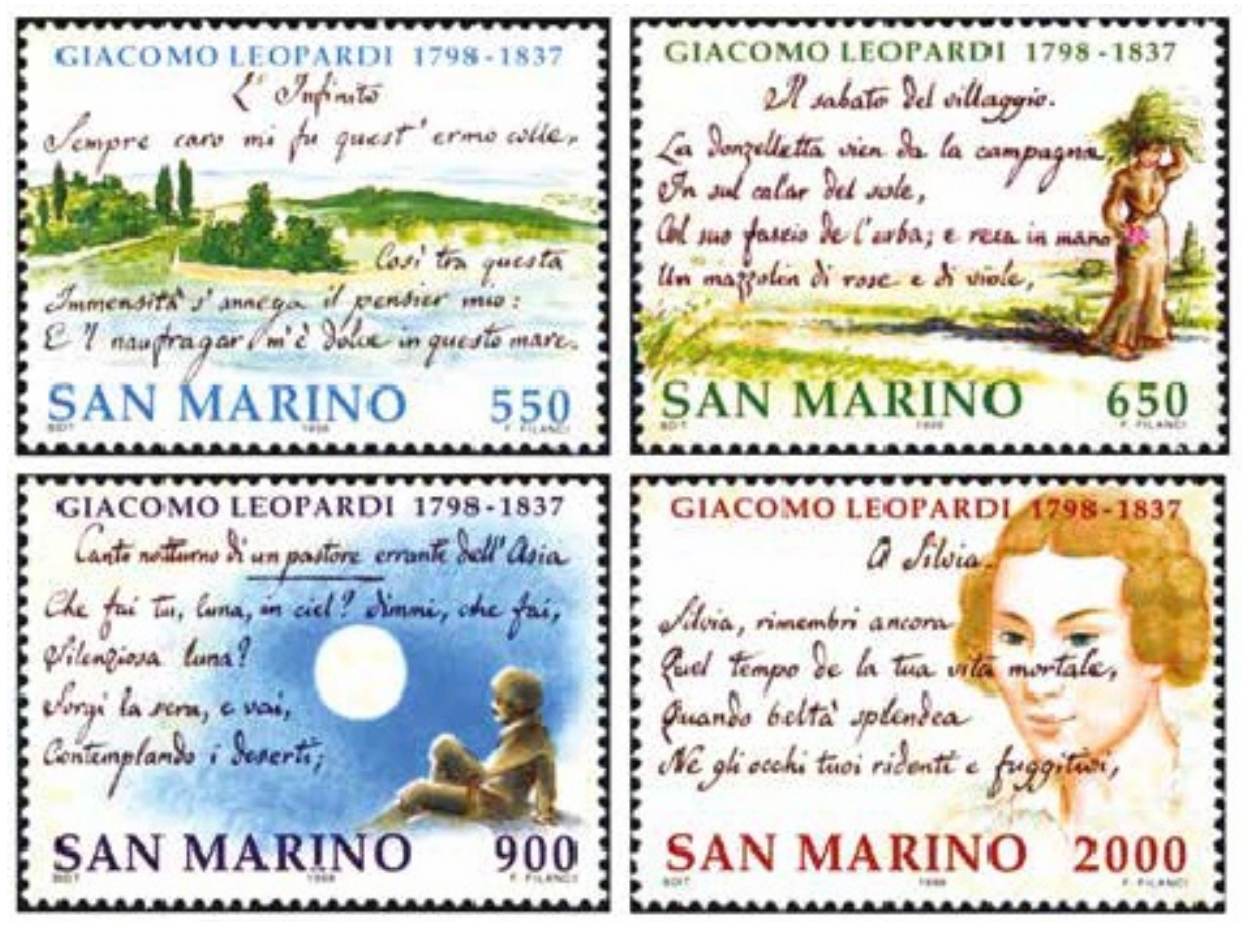

figure 4: Clockwise: San Marino, Scott 1417 (1998), "L’infinito"; San Marino, Scott 1418 (1998), "Il sabato del villaggio"; San Marino, Scott 1420 (1998), "A Silvia"; San Marino, Scott 1419 (1998), "Canto notturno di un pastore errante dell'Asia."

begin to relate to him with the compassion owed to a human being who lacked familial warmth in his formative years. I teach Leopardi as a realist philosopher of life's vicissitudes, rather than offering the more traditional view of him as a pessimist (some students argue that he is, in fact, a pessimist). And, to lighten up a bit the serious class conversations which are inevitable over the three or four weeks analyzing Leopardi's poems (Canti) and his Operette morali, I pull up on the class's large tech screen the commercial URL site https://despair.com, which is full of funny and ironic "demotivator" coffee mugs and posters. It gives students a bit of comic relief when Leopardi's thoughts delve deeply into the sad reality of human existence. Some students are already mature enough to appreciate the sense of profound loss that the poet experienced in his life, but other students risk falling into moments of depression themselves, especially depending on what might be going on in their own lives during the semester (stress, grades, academic deadlines, relationship breakups, or their own sense of isolation from their parents). In March 1998, the Republic of San Marino issued four stamps in occasion of the bicentenary of Leopardi's birth. Each replicates Leopardi's own elegant handwriting in parts of his poems "L'infinito," "Il sabato del villaggio," "Canto notturno di un pastore errante dell'Asia," and "A Silvia” [FIGURE 4]. 
This particular San Marino series on Leopardi is quite inexpensive, and readily to be found on auction sites on the internet. I bring my own set to class, in a protective plastic philatelic holder, and pass the stamps around on the days we discuss these particular "canti." Students comment that being able to see the poet's handwriting actually brings the author to life for them, as many of the poems we study in class were written when Leopardi was about their age. Leopardi is no longer just a name in a textbook for them. It is easy to enlarge these postage stamps and project them on the classroom's screen for all to see while we speak about them and Leopardi. Inevitably, the conversation moves to the art of calligraphy and the general lack of elegant calligraphic skills today, as most of us are used to keyboards to write papers, or even tiny cell-phone keyboards to text friends or jot down memos. Elegant calligraphy is a lost art-also in Italy. Students are fascinated by the artwork and its rules governing Leopardi's nineteenthcentury example of penning his own words.

The last author we study at length is Alessandro Manzoni, covering many of his poems and his historical novel I promessi sposi (The Betrothed) in its entirety. It is during the introductory lectures on Manzoni that I help better frame a European discourse on Romanticism. I am fortunate to have a wide choice of Italian postage stamps whose subject is Manzoni. In 1923 , on the fiftieth anniversary of his death, a set of six postage stamps was issued by the Italian Kingdom. Because this is a rather expensive set, valued anywhere between $\$ 700$ and $\$ 5,000$ depending on the condition of the stamps, teachers probably do not own it themselves. Due to their cost, plentiful forgeries of these stamps exist: caveat emptor for who might want to acquire them for a personal collection. For classroom needs, I find that simply copying and enlarging each stamp, then printing them, and handing them out to students works fine, keeping some margins around the image, so they can jot down notes as we speak. This set is quite remarkable, also in its artistic details. Because the first four designs represent scenes in I promessi sposi, the conversation weaves together both the theme of postage stamps, celebratory philatelic occasions and artistic critique, as well as analysis of the historical novel, focusing on the always-relevant question of artistic visual interpretations of a literary text (students are already quite skilled in discussing film adaptations from books, for instance). These scenes of the Manzoni-stamp series take place in northern Lombardy and the Lake Como regions, and a few of the enrolled students who have already visited these sites bring pictures and share them with the rest of the class. Geography comes alive in these four weeks dedicated to Manzoni and to his works.

The beautiful and detailed graphic design of the stamps' ornate frame is identical for the first four stamps, displaying vertical symmetrical images of white bas-relief marble or stonesculpted columns, against a colored background. Each stamp is printed in different ink colors: respectively brown, red, and black for Scott 165; blue, green, and black for Scott 166; black and slate for Scott 167; and orange, brown, and black for Scott 168. The ornate drawings turn more monumental and enduring for the last two stamps, whose colors are blue and black for Scott 169; and violet and black for Scott 170 [FIGURE 5]. 


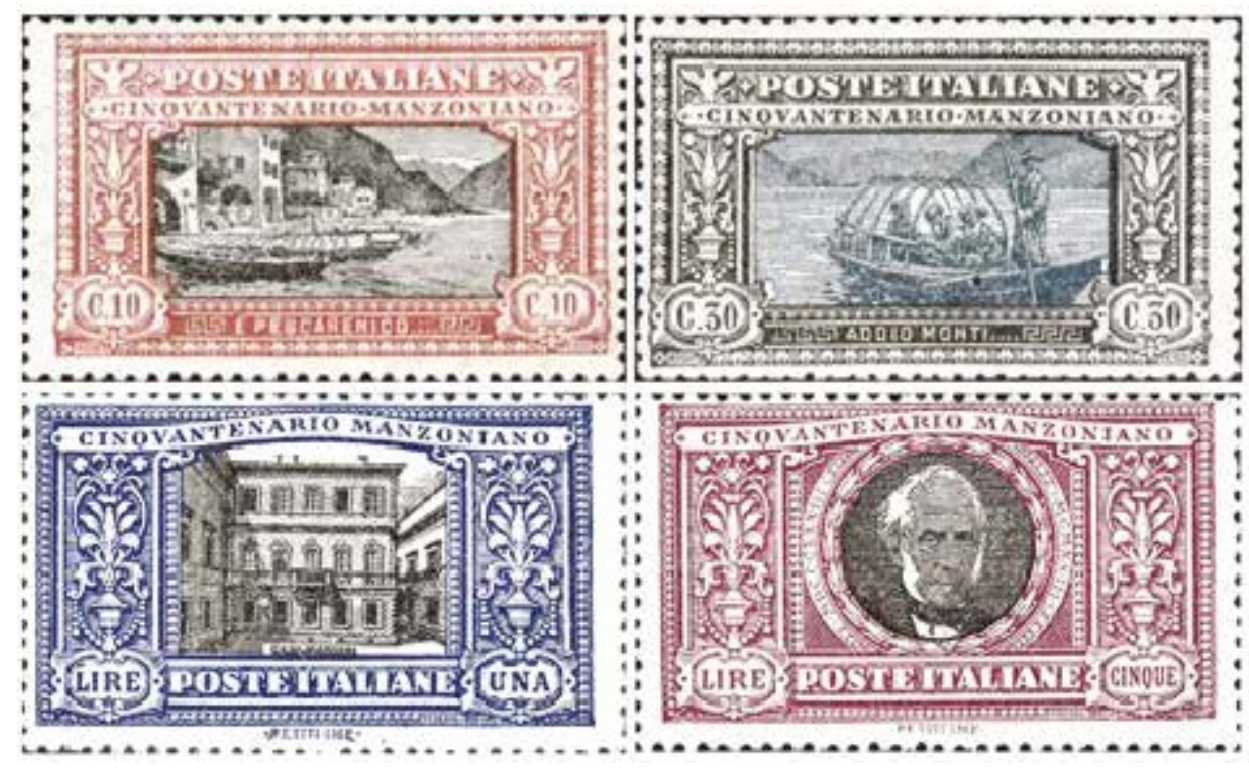

figure 5: Clockwise: Italy, Scott 165 (1923), Fishing scene at Pescarenico; Italy, Scott 167 (1923), Fugitives bidding farewell to native mountains; Italy, Scott 170 (1923), Alessandro Manzoni; Italy, Scott 169 (1923), Manzoni's home in Milan.

The teacher might project enlarged images of each stamp on the classroom's screen, to facilitate the discussion. When talking about Manzoni's house (Scott 169), an easy and quick internet search for contemporary photos of the facade of his home will bring up several images, and comparing them side by side with Scott 169 is helpful also in terms of architecture, style, and engineering (for those who might have some urban planning majors in class).

While I teach Manzoni, I allow plenty of time to create a tangent in the syllabus, straying from literature to music. This becomes necessary because Manzoni's death (celebrated in the stamps mentioned above) is musically connected to Giuseppe Verdi's Messa da Requiem. Many enrolled students already play musical instruments, read scores with ease, or sing in the university's choir, so conversing about music in the Italian Romanticism class feels overall comfortable. I leave ample time in the syllabus to introduce the concept of a requiem, to give a superficial, but decent, overview of its canonical Latin text (almost none of my students has studied Latin), to explain the traditional sequencing of movements, and, specifically, to introduce and discuss what I consider to be the four most important Requiem choral works that no undergraduate can ignore: those by Wolfgang Amadeus Mozart, Johannes Brahms, Giuseppe Verdi, and Benjamin Britten. ${ }^{17}$

17 As a graduate student in the 1980s at the University of Wisconsin-Madison, I was humbled and privileged to sing in the UW Choral Union (250 singers) under the direction of the legendary choral conductor, Prof. Robert Pratt Fountain (1917-96). Our choir performed together with the UW Madison Symphony. I am not a trained musician. The reason I know all four of these Requiems so well is because I had such an amazing teacher. Rather than telling us how to sing a part, Prof. Fountain taught us how we should feel when singing those parts of the score. I can still see him on the podium in front of all of us, saying "When you sing, feel the gloom and the desperation of death, here!" and "feel the light of salvation lifting your soul upwards, here, and sing it as you mean it!" and "here, you have to feel terrified and petrified by the possibility of eternal damnation in these notes!" etc. Prof. Fountain not only taught us breathing pauses, voice techniques, and how to respect a tempo while reading the score, he also taught us how to feel while expressing vocally the music of those black dots on the score. He taught me how to read and interpret a piece of music. His approach to music provided me with one of my most treasured teaching tools I used later, as a 
I insert these works into the syllabus because the political, cultural, and intellectual mood of every epoch permeates its architecture and music, as it does its literature and history. There are many postage stamps, issued worldwide, that portray these composers, whose images are widely available on the internet in public domain. Working in class chronologically through the four Requiems allows the students to actually "feel" and study the shift marking the end of the Baroque and Enlightenment eras, and the move towards the cultural and historical energy (and sense of hopelessness) of the proto- and pre-Romantic movements, in order for them to understand the courage and political engagement of the central Romantic decades, and finally to move out of Romantic art (very roughly considered as starting in the third quarter of the eighteenth century and extending through the third quarter of the nineteenth), eventually landing in the macro devastation of the large, encompassing, no-longer regional wars of the twentieth century. Through these choral works, I try to build a cultural and artistic chronological arc of the story of the Humanities from the end of the eighteenth century to the end of WWII, so that students can appreciate where European Romanticism came from, and what it led to, though not necessarily intentionally nor directly (fleetingly, we cover Nietzsche's concept of the Übermensch).

Mozart's Requiem (1791) carries many stylistic patterns of Baroque music, coupled with undertones for an optimistic resolution in a benevolent afterlife, as it ends in the light, allegro fugue movement "Cum sanctis tuis." Even in its most grave and solemn moments, there is underlying energy in the notes. My students, who all belong squarely to Generation Z, have not heard of Miloš Forman's movie Amadeus (1984), which won that year's Academy Awards for best picture, best actor, best director, best adapted screen play, best costume design, best production design, best sound mixing, and best makeup and hair styling. This list of accomplishments is generally sufficient to intrigue them, and most decide to stream the film on their own time. Mozart's music (including part of the Requiem) makes up almost all of the film's soundtrack, so class discussions become lively and informed.

Brahms' Ein deutsches Requiem (1865-68) is sung in German instead of Latin (why this is so is one of the main questions I ask the class). Its melodies range from the barely whispered pianissimo of the first measures of the choral score to the harmonious lofty and moderately lively choral movement in $3 / 4$ tempo "Wie lieblich sind deine Wohnungen" ("How lovely are Thy dwellings," from Psalm 84: 1-2, 4), to the final segment in F major,

professor of literature: move my students to "feel" a piece of poetry, a novel, an article, while at the same time analyzing carefully its textual merits. By academic formation, I am the intellectual child of Russian formalist theories and of textual explication and dissection, but I never neglect the essential added element of the emotional connection to a text, and I try to blend both methodologies when I teach my classes. 
Klein 15

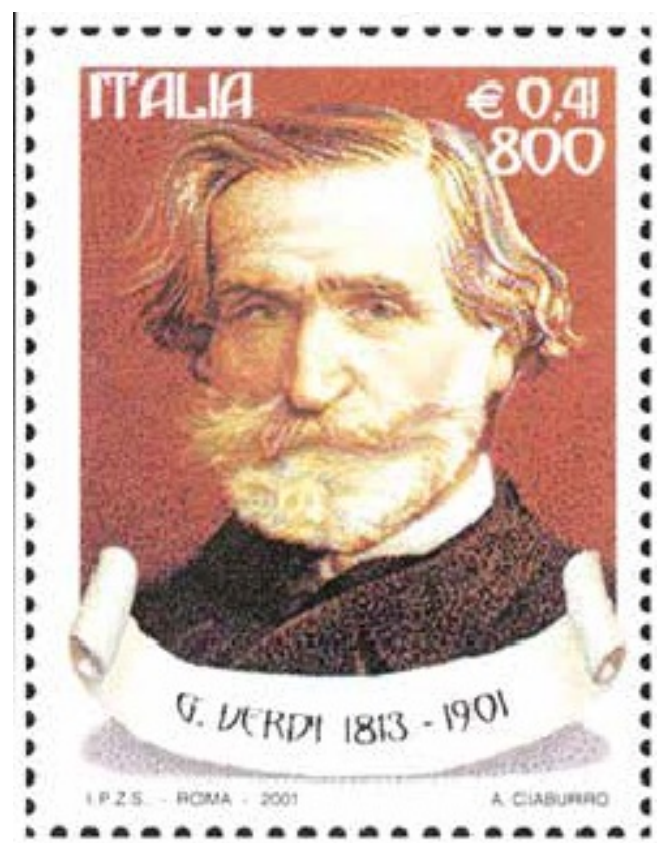

figure 6: Italy, Scott 2386d (2001), Verdi.

"Selig sind die Toten" ("Blessed are the dead"), which echoes the same score of the very first movement of his Requiem, "Selig sind, die da Leid tragen" (Blessed are those who carry sorrows"), making the whole work follow a musical circular pattern of deep introspection and questioning on the part of people seeking answers. I ask the class if there is a resolution to death in this Requiem. Why does this musical work end the way it began?

While not an actual class assignment, over the span of a couple of weeks, I encourage the students to listen to all four Requiems, and most of them do. Class discussions are enriched, because they are now based on actual listening experience, more than just on theory and class lectures. I then introduce Verdi's Messa da Requiem (first performed on 22 May 1874, on the one-year anniversary of Manzoni's death). In 2001, Italy issued a portrait stamp of the composer, part of a series of four (including Bellini, Cimarosa, and Spontini) and that, interestingly enough, has its postage value printed in both euros and liras currency (2001 was the year of the transition, of course). [FIGURE 6].

This gives us an opportunity to speak also about Europe's past and present monetary systems, and to look at some old mid-nineteenth century Italian stamps (mostly valued in hundredths of liras) and speculate about the value of coins at the time, and national inflation over the decades. Majors in finances enjoy these discussions. Unlike the previous two Requiems, much of Verdi's musical energy stems from movements of desperation, bondage, fear, and anger. Verdi admired Manzoni, and was deeply shaken by his death (Manzoni died of old age, nevertheless the nation was shocked). 
When the "Dies irae" movement goes into the terrifying "Tuba mirum" segment, the human voices are overpowered by the fortissimo doomsday notes blared by the trumpets. These convey the power of the wrath of God, and the ghastly fear of the souls waiting to be judged. I play recorded segments in class, and allow students some reflective time to feel these moods. The final movement, "Libera me," is not really as cathartic as one might expect, having listened to the two previous Requiems which provide a hopeful and possibly even compassionately forgiving ending. Instead, Verdi's Messa da Requiem keeps churning into the chaos of human uncertainty about the afterlife - the gnawing question of whether people are deserving of compassion and forgiveness - and this sense of fear for our ultimate fate permeates the last measures of the score. It is important to focus on this sense of unease about post-mortality and whether humankind is worthy of eternal peace when studying Manzoni's poems and prose works, because, as a man of deep faith, his religious message to readers is borne by a mixture of personal introspection of faith and duty, stoic resistance in the light of life's tragedies and untimely deaths, doubts about one's own worthiness, and inspiring moments of compassion and understanding for the goodness in others, mirrored by unselfish examples of human gestures of courage and solidarity. Verdi's opus focuses on the former, without treating the latter.

Benjamin Britten's War Requiem (1961-2) has a difficult score and is melodically full of dissonances, on purpose. The canonical Requiem text is interspaced by poems in the English language about war, authored by Wilfried Owen (1893-1918). Several students, especially the English majors, are already familiar with his works by the time they enroll in the Italian Romanticism class. My reason for including this War Requiem is to convey that the revolutionary wars of the nineteenth century in Europe were not the last expressions of political violence in the history of those nations. WWI and WWII saw the use of weapons of mass destruction on a scale never before imagined. Humanity has been left forever scarred by these recent wars and the millions of deaths. Britten's War Requiem shows, more than the other Requiems we discuss in class, the power of mankind to shatter what has taken centuries to build, to destroy bridges of human brotherhood. At this point in the course, the semester is coming to an end, and we are finishing Manzoni's last chapters of I promessi sposi. Manzoni's written words of comfort and hope for a better future human community of faith, cooperation, social justice, and love among people are, ironically, contraposed by the disheartening sadness described by Owen's words that portray the future that the twentieth and twenty-first centuries have created.

By the end of the semester, the undergraduate students in this seminar have learned to be comfortable with more questions than answers, for the semester's journey has taught them that simple, patterned answers to difficult questions do not exist. Over the previous fourteen weeks, they have honed their own skills, and have learned, in their own way, how to feel and read and react to a text, intellectually and emotionally. They can finally put nineteenth-century concepts into a wider humanistic frame of thought. Students can successfully articulate an academic, chronological narrative of how Italian Romanticism developed from the end of Enlightenment to the birth of Naturalism. More importantly, they have come to accept, value, and expect the development of human thought, politics, technology, economics, music, architecture, and literature to be polyvalent and nuanced in all of their non-linear manifestations. I believe that 
the most successful outcome of teaching an Italian Romanticism class with this interdisciplinary approach is that it ultimately allows students the freedom to build their own reasoned and academically supported construct, and to create their own narrative about the fascinating, troubling, energetic, violent, idealistic, and convoluted decades of European Romanticism.

At semester's end, most students remark ab out how much they enjoyed the hands-on approach with the philatelic items. I will share here a couple of more specific comments. After receiving her final (successful) grade, a student stopped by my office to chat about the course and mentioned her surprise when she reflected on the positive impact that the postage stamps had on her learning experience. When I brought them to class, she initially found the stamps to be "tangential" at best, but as the semester progressed, and more concepts were being developed, she recognized how important they were in helping her remember and consolidate the topics that we had covered up to that point, while reviewing for the midterm and final exams. She said that the images narrated a chronological story that pulled together all the threads that we had discussed in class. Another student pointed out to me in an email that seeing Manzoni's house on a stamp in class (i.e., Scott 169) later prompted him to visit it during his trip to Milan the following summer, and how surprised he was that "it still looks just like that!" He also wrote that seeing the Italian Romantic authors on official postage stamps confirmed for him that the texts we studied in class "had a significant cultural impact in Italy."

In class, students show enthusiasm about postage stamps, and the conversations are always lively with the presence of such realia. However, honesty demands that I mention that after years of teaching Italian Romanticism with postage stamps, I have failed miserably in my hidden agenda of trying to instill in the younger generation a passion for stamp collecting. Over the years, there has been a grand total of only two students who, after taking the class, have pursued philately as a hobby. I fear that we are a dying breed of philatelic dinosaurs. ... 